\title{
Salinity guidelines for irrigation: Case studies from Water Research Commission projects along the Lower Vaal, Riet, Berg and Breede Rivers
}

\author{
LD van Rensburg ${ }^{1 *}$, WP de Clercq ${ }^{2}$, JH Barnard' and CC du Preez ${ }^{1}$ \\ ${ }^{1}$ Department of Soil, Crop and Climate Sciences, University of the Free State, PO Box 339, Bloemfontein 9300, South Africa \\ ${ }^{2}$ Department of Soil Science, University of Stellenbosch, Private Bag X1, Matieland, Stellenbosch 7602, South Africa
}

\begin{abstract}
A vast number of projects on salinity in irrigated agriculture were funded by the Water Research Commission (WRC) during the past 40 years. However, due to the diversity of the projects it is virtually impossible to cover all aspects thoroughly in a paper of limited length. Thus this review focuses mainly on projects along the Lower Vaal, Riet, Berg and Breede Rivers in South Africa. The results on the water quality of these rivers indicate that irrigation has led to the deterioration of water sources. There is a direct relationship between river water quality and soils irrigated. Fortunately, effective landsuitability guidelines were developed and applied during the establishment of the major irrigation schemes. This facilitated the management of soils under irrigation. The results from long-term irrigation case studies along the Lower Vaal River and Breede River show that the quality of soils can be improved. The opposite is also true where mismanagement occurred. Research on the salinity threshold of major crops (grapevines, wheat, maize, groundnuts, etc.) confirmed the empiric nature of the guidelines. It is suggested that a more dynamic approach be used for managing salinity under irrigation at farm level, i.e. the use of models. Amongst others, future research should focus on determining the spatial and temporal distribution of salt in irrigated soils.
\end{abstract}

Keywords: crop response, electrical conductivity, sodium adsorption ratio, soil type, water quality

\section{Introduction}

Irrigation contributes significantly to crop production in South Africa since the country does not have rainfall in abundance (Backeberg, 2003). The mean annual precipitation for the country as a whole is only $480 \mathrm{~mm}$. It follows that sustained food production in some of the drier provinces is only possible with irrigation. For example, in the Western Cape virtually the entire fruit and wine industries are dependent on irrigation. Cropping in the Eastern and Northern Cape also relies heavily on irrigation. Salinisation of water resources in these provinces is therefore of great concern for irrigation. High levels of salinity impact negatively on soil quality and crop yield.

According to various reports published during the 1960s to 1980 s, the salinity of South Africa's water resources has been deteriorating steadily, albeit slowly (Stander, 1987). This has been true especially for rivers and storage dams in the Gauteng industrial area (Stander, 1987) and in the semi-arid south-western and south-eastern parts of South Africa (Fourie, 1976). At that stage problems associated with salinity in irrigated agriculture had already been encountered in some of these areas. Some examples are the irrigation schemes of the Fish and Sundays Rivers in the Eastern Cape (Hall and Du Plessis, 1979), the Riet River in the Free State (Van der Merwe, 1965), the Berg and Breede Rivers in the Western Cape (Cass, 1986) and the Vaalharts Irrigation Scheme in the Northern

This paper was originally presented at the Water Research Commission 40-Year Celebration Conference, Kempton Park,

31 August - 1 September 2011.

* To whom all correspondence should be addressed.

om +27 51 401-2957; fax: +27 51 401-2212;

e-mail: vrensbl@ufs.ac.za
Cape (Streutker et al., 1981). These earlier studies were sporadically conducted by either the Department of Agriculture or the Department of Water Affairs to solve problems experienced by irrigation farmers. However, research undertaken at the University of the Free State, Rhodes University and Stellenbosch University also contributed to our knowledge.

During the 1970s and even the 1980s elevated salinity levels were attributed to the quality of water received from the Department of Water Affairs (DWA) for distribution to users. The idea that water quality in rivers and hence storage dams could be affected by land use was not generally accepted. The department decided therefore not to monitor land salinity, but to intensify water quantity and quality measurement in rivers. This resulted in an expansion of the DWA's database, which originated in the 1960 s, to one of the largest national attributes for planning and research concerning water resources. In retrospect it was a good decision by the DWA.

Fortunately, in 1971 the Water Research Commission (WRC) was founded to coordinate water research in South Africa. This resulted in research prioritisation. Cass (1986) for example, was commissioned to take stock of water-quality data suitable for modelling irrigation return flows. He concluded that insufficient long-term data sets existed, particularly on soils and crops for this purpose, with the exception of data collected by Streutker et al. (1981) for the Vaalharts area. This finding of Cass (1986), and recommendations made in reviews on the degradation of irrigated soils (Scotney and Van der Merwe, 1995) and irrigation water quality (Du Plessis, 1995), led to a substantial number of WRC projects, spanning 40 years, which dealt in one way or another with salinity management under irrigation (e.g. Cass, 1986; Nel, 1988; Greef, 1990; Moolman, 1993; Herold and Bailey, 1996; Herald, 1999; Moolman et al., 1999; Du Preez et al., 2000; De Clercq et al., 2001a; b; Ehlers et al., 2003; Ellington et al., 2004; Fey and 
Figure 1

Location of the rivers selected for the waterLower Vaal River and its tributaries (Harts and Riet Rivers), Berg River and the Breede River quality review: The

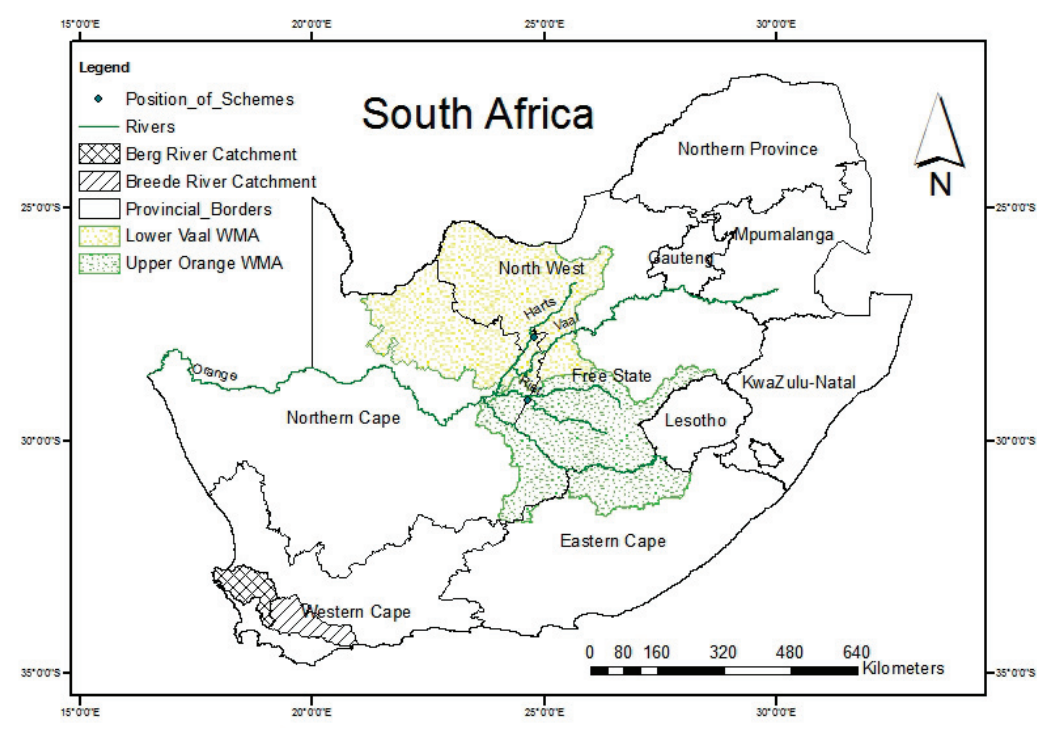

De Clercq, 2004; Cullis et al., 2005; Görgens and De Clercq, 2006; Viljoen et al., 2006; Ehlers et al., 2007). The projects were diverse and covered topics such as hydrology, soils, crops, economy and modelling.

The diversity of the WRC projects makes it virtually impossible to cover all aspects thoroughly in a paper of limited length. Thus this paper focuses on salinity guidelines for irrigation with respect to selected rivers, soils and crops within the summer- and winter-rainfall regions. Case studies along the Vaal, Harts and Riet Rivers were selected to represent the summer-rainfall region and those along the Berg and Breede Rivers for the winter-rainfall region. The methodologies applied in these case studies are readily available in the relevant WRC reports and are therefore not repeated, except where essential to support results that are discussed herein.

\section{Irrigation and river water quality}

This section focuses on the effect of irrigation on the quality of water along the course of selected rivers, namely the Lower Vaal River and its tributaries (Harts and Riet Rivers), Berg River and Breede River (Fig. 1). The Lower Vaal River and its tributaries are located in the summer-rainfall area, while the Berg and Breede rivers are situated in the winter-rainfall area. The Lower Vaal River and its tributaries supply water to irrigate 80000 ha of land, viz. 58000 ha along the Lower Vaal River, 19500 ha along the Riet River and 2500 ha along the Harts River. Farmers irrigate mainly field crops (maize, wheat, groundnuts, peas, oats, potatoes, etc.), pastures like lucerne and teff, and small areas of perennials (vineyards, pecans, citrus and olives) (Herold and Bailey, 1996; Ninham Shand, 2004). For the Berg River, only $6 \%$ of the land surface area is related to irrigation and explains the absence of an irrigation scheme. Thus land use is mainly allocated to dryland agriculture (mainly wheat). The Breede River Valley forms part of drainage region $\mathrm{H}$ (DWAF, 1986) and is an important agricultural area for the production of high-value crops under intensive irrigation. Irrigated agriculture accounts for more than $80 \%$ of the total water use in drainage region $\mathrm{H}$. There is a wide and dynamic crop mix, but wine is the primary product with $65 \%$ of the area under wine-grape varieties. Other crops produced in the valley are peaches and apricots $(13 \%)$, vegetables, mainly tomatoes (3\%) and irrigated pastures (7\%) (Moolman et al., 1999).
Since the 1950s, the Department of Water Affairs and Forestry (DWAF) collected water quality data on the major river systems in South Africa (Du Preez et al., 2000). The data were used to assess the broader impact of irrigation and other anthropogenic factors on the water quality of the selected rivers. The quality parameters were: calcium, magnesium, sodium, potassium, silicon, sulphate, chloride, fluoride, ammonium, nitrate, nitrite, phosphorus, $\mathrm{pH}$, calcium carbonate (total alkalinity) and electrical conductivity (EC). Of these parameters, EC and sodium adsorption ratio (SAR, derived from $\mathrm{Na}$, $\mathrm{Ca}$ and $\mathrm{Mg}$ concentrations) are discussed. The results of the long-term mean EC and SAR for the rivers have been summarised and are given in Table 1. It was not possible to estimate the 2020 impact of irrigation on the water quality of Berg and Breede Rivers.

\section{Lower Vaal River and tributaries}

The water quality of the Lower Vaal River reflects the irrigated agriculture sector, because water use by industries and municipalities is relatively low. The results in Table 1 show clearly that EC and SAR increased along the course of the rivers. For example, the Vaalharts Irrigation Scheme (Fig. 2) abstracts water from the Vaalharts weir (C2S1 class) and discharges most of the leachate and excess water into the Harts River. This management system causes the water quality of the Harts River to deteriorate from a C2S1 class (above discharge) to a C3S1 class (below discharge). The problem is that the water flows into Spitskop Dam where it is further used to irrigate mainly clay soils. Fortunately, the sodium load of the water is low and the EC is high, which means that the infiltration capacity of the soils is not seriously affected. However, users of Spitskop Dam water should be aware of this situation and the need to adopt best management practices to sustain irrigation farming in the long run. The long-term projection (2020) of Du Preez et al. (2000) indicated that the SAR will increase to just above 6, which implies that the hydraulic properties of the clay soils will be degraded. If this happens farmers might be forced to install artificial drains to leach the excess salts. Thus, the current water management option will bring about huge costs for future farming downstream of Vaalharts Irrigation Scheme. Excess water from Spitskop scheme drains back into the Vaal River near Delportshoop. The salt is then transported downstream where it blends with water from the Riet River. 


\begin{tabular}{|c|c|c|c|}
\hline \multicolumn{4}{|c|}{$\begin{array}{c}\text { Table } 1 \\
\text { Long-term mean electrical conductivity (EC, mS·m }{ }^{-1} \text { ) } \\
\text { and sodium adsorption ration (SAR) for rivers } \\
\text { associated with selected irrigation schemes } \\
\text { (data from Du Preez et al., 2000) }\end{array}$} \\
\hline \multirow[t]{2}{*}{ River } & \multirow[t]{2}{*}{ Measuring points } & \multicolumn{2}{|c|}{$\begin{array}{c}\text { Long-term } \\
\text { mean }\end{array}$} \\
\hline & & $E C$ & SAR $^{*}$ \\
\hline \multirow{4}{*}{ Vaal } & $\begin{array}{l}\text { Bloemhof Dam downstream to } \\
\text { Vaalharts Weir }\end{array}$ & 52 & 1.2 \\
\hline & $\begin{array}{l}\text { From Vaalharts Weir downstream to } \\
\text { Vaalharts confluence at Delportshoop }\end{array}$ & 54 & 1.3 \\
\hline & $\begin{array}{l}\text { From Delportshoop downstream to the } \\
\text { Vaal-Orange confluence }\end{array}$ & 72 & 1.8 \\
\hline & $\begin{array}{l}\text { From the Vaal-Riet confluence, down- } \\
\text { stream to the Vaal-Orange confluence }\end{array}$ & 74 & 1.9 \\
\hline \multirow{2}{*}{ Harts } & $\begin{array}{l}\text { Schweizer-Reneke, downstream to } \\
\text { Taung }\end{array}$ & 70 & 2.3 \\
\hline & $\begin{array}{l}\text { From Taung, downstream to } \\
\text { Delportshoop }\end{array}$ & 115 & 2.4 \\
\hline \multirow[b]{2}{*}{ Modder } & Upstream of Krugersdrift Dam & 48 & 1.16 \\
\hline & $\begin{array}{l}\text { From Krugersdrift Dam downstream } \\
\text { to the confluence of Modder/Riet }\end{array}$ & 63 & 1.49 \\
\hline \multirow{3}{*}{ Riet } & From Jacobsdal upstream & 51 & 1.43 \\
\hline & $\begin{array}{l}\text { Orange-Riet canal at Riet River } \\
\text { scheme }\end{array}$ & 21 & 0.39 \\
\hline & $\begin{array}{l}\text { Downstream of the confluence of the } \\
\text { Riet/Modder }\end{array}$ & 136 & 3.17 \\
\hline \multirow{3}{*}{ Orange } & Upstream of Hopetown & 17 & 0.33 \\
\hline & $\begin{array}{l}\text { Between Hopetown and the Vaal- } \\
\text { Orange confluence }\end{array}$ & 19 & 0.38 \\
\hline & $\begin{array}{l}\text { Downstream of the Vaal-Orange } \\
\text { confluence }\end{array}$ & 23 & 0.53 \\
\hline
\end{tabular}

Drastic measures were taken in the past to control the effluent of the irrigation sector along the Riet River (Fig. 3). Water of a high quality (C1S1) is transferred via the OrangeRiet Canal to the Jacobsdal Irrigation Settlement and the excess water as well as the drainage effluent is discharged into the Riet River. Despite this effort the water quality of the river downstream of the confluence of the Riet and Modder Rivers remained a C3S1 class. This can be ascribed to the salt load of the Modder River (C2S1), Riet River (C2S1) and the lithology of the catchment. The salts in the soils and sediments are mobilised through irrigation activities and the effluent drains to the river to be used by irrigators downstream. The 2020 prediction revealed that the EC will increase from long-term (1971-1997) average values of $136 \mathrm{mS} \cdot \mathrm{m}^{-1}$ to $157 \mathrm{mS} \cdot \mathrm{m}^{-1}$ and the SAR from 3.2 to 4.6. This implies that extension officers and advisors need to promote best management practices to avoid the negative impact of the salt load on soils and crops along the Riet River.

\section{Berg and Breede Rivers}

The water quality results of the rivers are presented in Table 2 , and patterns along the main streams of the Berg and Breede Rivers are shown in Fig. 4 and Fig. 5, respectively. The chronic water shortage during the summer season due to the absence of rain is a major problem in these rivers. During this period water seeps from the crop fields into the tributaries, causing the water quality to deteriorate, as indicated in the results. This

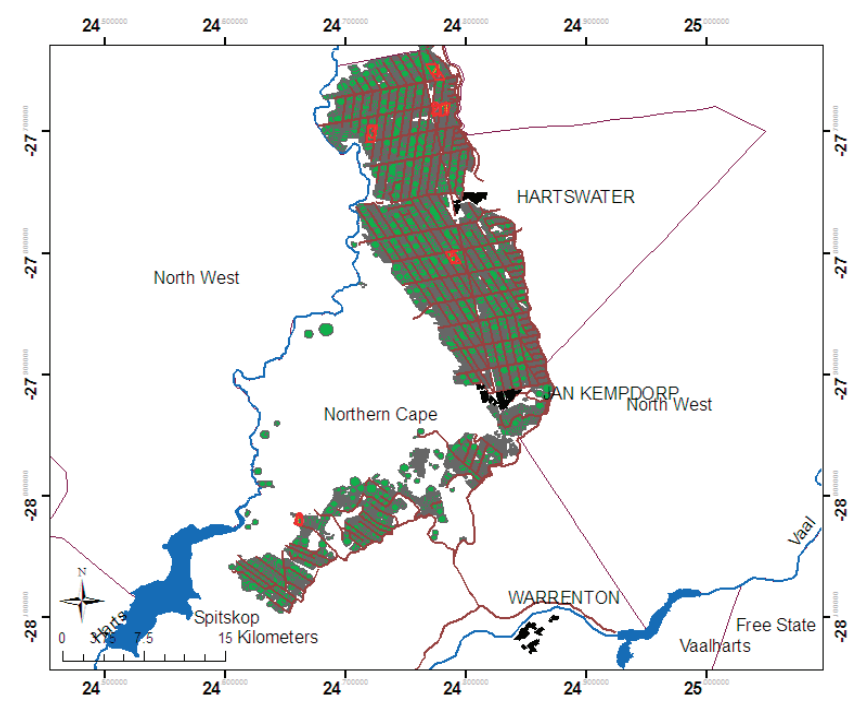

Figure 2

Layout of the Lower Vaal River with the Harts River as a tributary

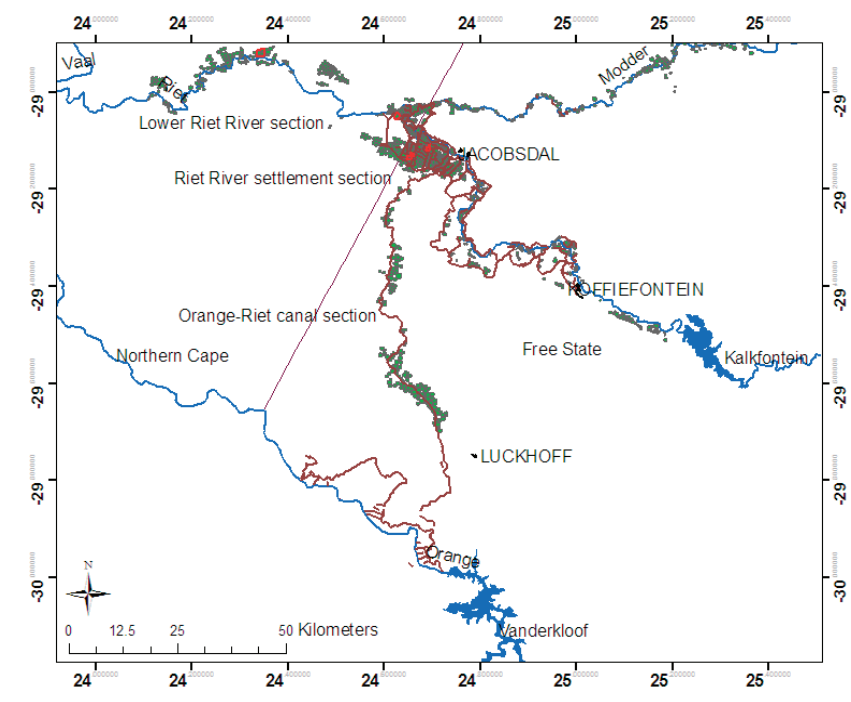

Figure 3

Layout of Orange - Riet Irrigation Scheme, showing the Riet and Modder Rivers in relation to the Orange River

effect suggests that water flow in the river should be managed by the water user associations (WUAs). For example, the results indicated higher average EC values measured at the Nuy and Kogmanskloof River tributaries. During the period 1981 to 1990 the mean annual salinity rate increased for four of the principle tributaries of the Breede River between Worcester and Bonnievale. The mean annual salinity ranged from 38 $\mathrm{mg} \cdot \ell^{-1} \cdot \mathrm{a}^{-1}$ for the Kogmanskloof River to $145 \mathrm{mg} \cdot \ell^{-1} \cdot \mathrm{a}^{-1}$ for the Poesjesnel River (Kienzle, 1990). Similar data exist for the Berg River and the natural trends of increased salinity at the time (1976 to 1990) are alarming. It is also quite evident from the Berg River data that the water quality of the main stream was affected by the tributaries, in most cases increasing the salinity of the Berg River.

Since both river systems also supply water to the fast-growing Cape Town metropolis, the lack of water during summer months is currently posing an increased problem for the farming communities of these catchments. De Villiers (2007) and 


\begin{tabular}{|c|c|c|c|}
\hline \multicolumn{4}{|c|}{$\begin{array}{c}\text { Table } 2 \\
\text { The long-term median and maximum electrical } \\
\text { conductivity }(E C) \text { values for the Berg and Breede Rivers } \\
\text { of the Western Cape showing only selected measuring } \\
\text { points (De Clercq et al., 2001a) }\end{array}$} \\
\hline River & Measurement point & $\begin{array}{c}E C\left(\mathrm{mS} \cdot \mathrm{m}^{-1}\right) \\
\text { Median }\end{array}$ & $\begin{array}{c}E C\left(m S \cdot m^{-1}\right) \\
\text { Maximum }\end{array}$ \\
\hline \multirow{5}{*}{ Berg } & Paarl & 10 & 19 \\
\hline & Hermon & 21 & 42 \\
\hline & \begin{tabular}{|l|} 
Drieheuwels \\
\end{tabular} & 24 & 68 \\
\hline & Misverstand & 35 & 97 \\
\hline & Jantjiesfontein & 82 & 481 \\
\hline \multirow{8}{*}{ Breede } & Ceres & 24 & 60 \\
\hline & \begin{tabular}{|l|} 
Nekkies \\
\end{tabular} & 10 & 32 \\
\hline & Nuy River & 385 & 653 \\
\hline & \begin{tabular}{|l|} 
Le Chasseur \\
\end{tabular} & 24 & 62 \\
\hline & Kogmanskloof River & 305 & 531 \\
\hline & \begin{tabular}{|l} 
Wolvendrift \\
\end{tabular} & 70 & 320 \\
\hline & Drew & 82 & 234 \\
\hline & Swellendam & 53 & 171 \\
\hline
\end{tabular}

Nieuwoudt et al. (2008) indicated that, with the addition of the new Franschhoek Dam and subsequent increase in the storage capacity of dams in the Berg River catchment, the reduction in the occurrence and effectiveness of floods to lower the salinity levels in the main stream may also be a potential cause for concern in future.

\section{Irrigation and soil quality}

\section{Guidelines for evaluating irrigated soils}

Evaluation of the suitability of soils for irrigation is the key element in sustaining long-term quality of irrigated soils. This was the view of many soil scientists who surveyed soils of major irrigation schemes in South Africa; Sundays River, the Great Fish River and Hartbeespoort Dam (1912-1930), followed by Vaalharts, Pongola, Riet River and Lower Orange River (1930-1940). The surveyors were very strict in their application of soil suitability guidelines for irrigation. As they gained experienced they also improved these guidelines (Verster and Stofberg, 1974; MacVicar, 1976; Irrigation Planning Staff, 1980; Hensley and Laker, 1980; Bester and Liengme, 1989). The latest guidelines include 2 terrain properties (topography and the need for drainage), 4 soil physical properties (effective depth, texture, structure and coarse fragments) and 2 soil chemical properties (Schoeman, 1987). The norms for the 2 chemical properties ( $E C_{\mathrm{e}}$ and $\mathrm{SAR}$ ) were established by United States Salinity Laboratory Staff (1969). Soils are classified as either saline $\left(E C_{\mathrm{e}}>400 \mathrm{mS} \cdot \mathrm{m}^{-1}, \mathrm{SAR}<15\right.$ and $\left.\mathrm{pH}<8.5\right)$; sodic $\left(E C_{\mathrm{e}}<400 \mathrm{mS} \cdot \mathrm{m}^{-1}, \mathrm{SAR}>15\right.$ and $\left.\mathrm{pH}>8.5\right)$ or sodic-saline $\left(E C_{\mathrm{e}}>400 \mathrm{mS} \cdot \mathrm{m}^{-1}, \mathrm{SAR}>15\right.$ and $\left.\mathrm{pH}>8.5\right)$. Schoeman (1987) developed a 5 -class land-suitability guide (classes ranging from Class I to Class V), incorporating 6 soil properties to derive the potential hazard of irrigation to the soil, crop and environment. For example, a Class I soil poses no hazard to the sustainable management of the soil, crop and environment and is regarded as highly suitable for irrigation. A Class V soil, on the other hand, is unsuitable for irrigation because of the potential hazard to the soil, crop and environment. Thus management inputs intensify from Class I to Class IV with Class V is perceived as non-irrigable.

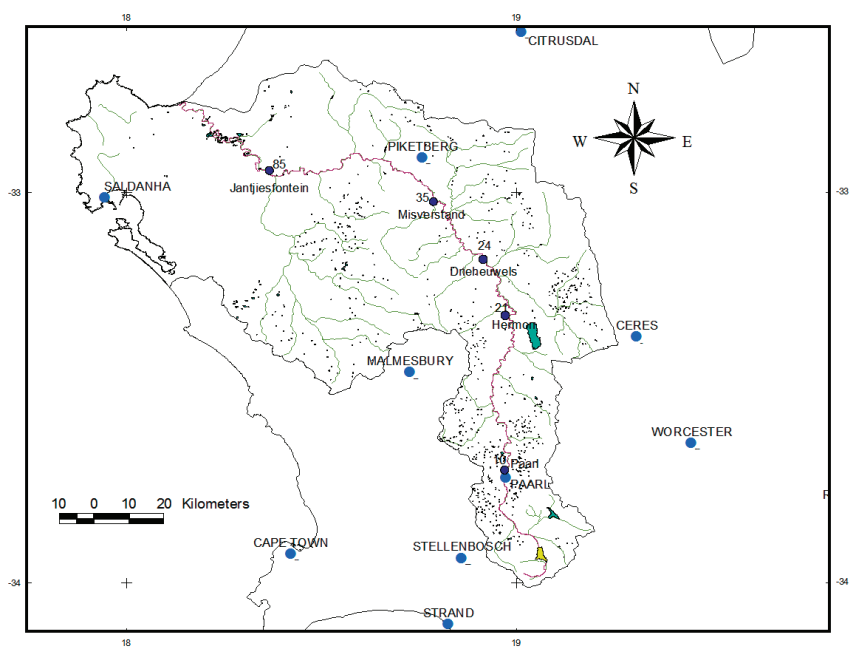

Figure 4

The Berg River catchment indicating the river system and the major dams and the electrical conductivity (EC) measurements at selected points (see Table 2)

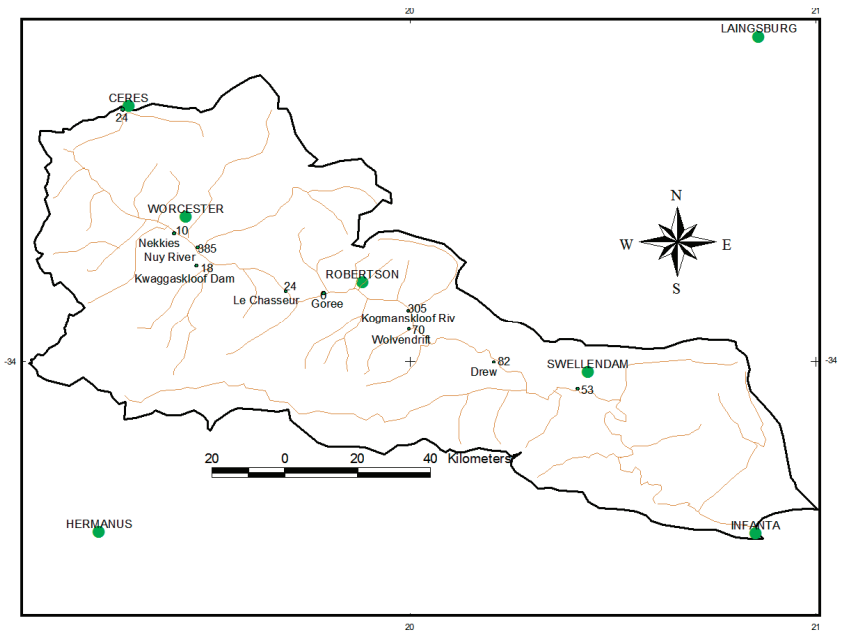

Figure 5

The Breede River catchment indicating the river system and the major dams and the electrical conductivity $(E C)$ measurements at selected points (see Table 2)

\section{National perspective on quality of irrigated soils}

Management of irrigated land is of utmost importance at national, local and farm level. For national purposes, Backeberg et al. (1996) estimated the area under irrigation for the provinces of South Africa (Table 3). The land was further divided into suitability classes: Class I is 'highly suitable', Class II 'suitable' and Class III 'risky'. These results indicate that $48 \%$ of the total irrigated area is regarded as 'highly suitable', $39 \%$ as 'suitable' and $13 \%$ as 'risky'. The irrigated land areas in Gauteng, Mpumalanga and North West are of a high quality, while Eastern Cape, KwaZulu-Natal, and Limpopo have significant portions of irrigated land in the risky class. The Western Cape has the largest area under irrigation, but a large portion (52 637 ha; 4\% of the irrigated area of South Africa) falls in the 'risky' class (Class III). Thus, from these results a conclusion can be made that the soil quality of the irrigated land seems satisfactory. This can be attributed to 


\begin{tabular}{|c|c|c|c|c|c|c|c|c|}
\hline \multicolumn{9}{|c|}{$\begin{array}{c}\text { Table } 3 \\
\begin{array}{c}\text { Distribution of land (ha and percentage of total irrigated land) under irrigation in the different provinces of } \\
\text { South Africa in relation to land suitability classes (data from Backeberg et al., 1996) }\end{array}\end{array}$} \\
\hline \multirow[t]{2}{*}{ Provinces } & \multicolumn{2}{|c|}{ Class I } & \multicolumn{2}{|c|}{ Class II } & \multicolumn{2}{|c|}{ Class III } & \multicolumn{2}{|c|}{ Total } \\
\hline & ha & $\%$ & ha & $\%$ & ha & $\%$ & ha & $\%$ \\
\hline Eastern Cape & 34568 & 3 & 94993 & 7 & 25367 & 2 & 154928 & 12 \\
\hline Free State & 39104 & 3 & 41131 & 3 & 18745 & 1 & 98980 & 8 \\
\hline Gauteng & 16925 & 1 & 6895 & 1 & 2864 & 0 & 26684 & 2 \\
\hline KwaZulu-Natal & 66627 & 5 & 71762 & 6 & 31855 & 2 & 170244 & 13 \\
\hline Mpumalanga & 129225 & 10 & 25426 & 2 & 2769 & 0 & 157420 & 12 \\
\hline Northern Cape & 80965 & 6 & 71356 & 6 & 9553 & 1 & 161874 & 13 \\
\hline Limpopo & 61752 & 5 & 46898 & 4 & 26496 & 2 & 135146 & 10 \\
\hline North West & 83660 & 6 & 16306 & 1 & 3352 & 0 & 103318 & 8 \\
\hline Western Cape & 100861 & 8 & 128038 & 10 & 52637 & 4 & 281536 & 22 \\
\hline Total & 613687 & 48 & 502805 & 39 & 173638 & 13 & 1290130 & 100 \\
\hline
\end{tabular}

\begin{tabular}{|c|c|c|c|c|c|c|c|c|c|}
\hline \multicolumn{10}{|c|}{$\begin{array}{c}\text { Table } 4 \\
\text { General description of soil-sampling sites and their properties along the Vaal River (Du Preez et al., 2000) }\end{array}$} \\
\hline \multirow[t]{2}{*}{ Site } & \multirow[t]{2}{*}{ Profile } & \multirow{2}{*}{$\begin{array}{l}\text { Soil } \\
\text { form }\end{array}$} & \multirow{2}{*}{\begin{tabular}{|l|} 
Irrigation \\
type
\end{tabular}} & \multirow[b]{2}{*}{ Years } & \multirow{2}{*}{$\begin{array}{l}\text { Water table } \\
\text { depth }(\mathrm{mm})\end{array}$} & \multirow[t]{2}{*}{$E C_{\mathrm{e}}^{*}$} & \multirow[t]{2}{*}{ SAR $^{* *}$} & \multirow{2}{*}{$\begin{array}{c}\text { Salt } \\
\text { content } \\
\left(\mathbf{k g} \cdot \mathbf{h a}^{-1} \cdot \mathbf{m}^{-1}\right)\end{array}$} & \multirow{2}{*}{$\begin{array}{c}\text { Difference } \\
\text { from } \\
\text { reference } \\
\text { profile } \\
\end{array}$} \\
\hline & & & & & & & & & \\
\hline \multirow[t]{4}{*}{ Vaalharts } & Virgin sand & Hutton & None & & $\mathrm{np} * * *$ & 18 & 0.6 & 423 & \\
\hline & Irrigated sand & Bainsvlei & Flood & 53 & 1600 & 90 & 1.3 & 2002 & +1579 \\
\hline & Virgin clay & \begin{tabular}{|l|} 
Valsrivier \\
\end{tabular} & None & & $\mathrm{np}$ & 76 & 5 & 5420 & \\
\hline & Irrigated clay & Valsrivier & Flood & 53 & $\mathrm{np}$ & 128 & 2.7 & 4379 & -1041 \\
\hline \multirow{2}{*}{ Wildeklawer } & Virgin sand & Hutton & None & & $\mathrm{np}$ & 40 & 0.7 & 1469 & \\
\hline & Irrigated sand & Bainsvlei & Centre pivot & 53 & $\mathrm{np}$ & 137 & 2.2 & 4545 & +3076 \\
\hline \multirow[t]{2}{*}{ Spitskop } & Virgin clay & Arcadia & None & & $\mathrm{np}$ & 63 & 2.3 & 2578 & \\
\hline & Irrigated clay & Arcadia & Flood & 53 & $\mathrm{np}$ & 464 & 7.3 & 22864 & +20286 \\
\hline \multirow[t]{3}{*}{ Jackson } & Virgin sand & Bloemdal & None & & 1300 & 153 & 7.5 & 4617 & \\
\hline & Irrigated sand & Bloemdal & Centre pivot & 45 & 1100 & 60 & 2.3 & 1868 & -2749 \\
\hline & Irrigated clay & Sepane & Flood & 45 & 1200 & 1224 & 19 & 84750 & \\
\hline
\end{tabular}

*Electrical conductivity measured in a saturated paste

**Sodium adsorption ratio, derived from $\mathrm{Na}, \mathrm{Ca}$ and $\mathrm{Mg}$ concentrations

***np: not present

the strong criteria of soil selection enforced by Department of Agriculture. However, soil quality can change rapidly under irrigation as will be seen in the next section.

\section{Soil quality along the Vaal River}

The WRC report of Du Preez et al. (2000) provided insight into soil-quality changes caused by long-term irrigation. Du Preez et al. (2000) sampled virgin and irrigated soil profiles along the Vaal River. The profiles were sampled at Vaalharts, Spitskop, Wildeklawer, Zandbult and Jackson during March 1998 to a depth which was limited by either a hard layer (dry sandy loam and clay soils), a water table (some irrigated soils) or a maximum depth of $2000 \mathrm{~mm}$. Each profile was described in situ according to the format of Turner (1991) and classified according to the Soil Classification Working Group (1991).

Du Preez et al. (2000) used the following materials and methods: Every profile was marked in depth intervals of 200 $\mathrm{mm}$ and then sampled. Additional soil samples were also collected at the same depth intervals with either a Thompson or Edelman soil auger about $5 \mathrm{~m}$ away in all 4 wind directions from a profile pit. This was to check whether the salt content of a pit was representative of the site. The soil samples were dried at about $40^{\circ} \mathrm{C}$, crushed to pass through a $2 \mathrm{~mm}$ sieve, thoroughly mixed and stored in glass bottles until analysed using standard methods (The Non-Affiliated Soil Analysis Work Committee, 1990). The analyses included particle-size distribution (organic matter and carbonates were not removed, but the Calgon aliquot was increased from $10 \mathrm{~m} \ell$ to $50 \mathrm{~m} \ell$ and a hydrometer was used), electrical resistance and water content of a saturation paste, electrical conductivity $\left(E C_{\mathrm{e}}\right)$ and cation $(\mathrm{Ca}, \mathrm{Mg}$ and $\mathrm{Na}$ ) content of the saturation paste extract. The concentrations of the cations were determined by atomic absorption spectrometry. SAR was estimated from the concentration of $\mathrm{Na}, \mathrm{Ca}$ and $\mathrm{Mg}$ in the saturation paste extract.

The results of the soils sampled along the Vaal River are summarised in Table 4. In total 6 soil forms were identified: Hutton, Bloemdal, Bainsvlei, Valsrivier, Sepane and Arcadia forms (Soil Classification Working Group, 1991). None of the virgin soils were saline, sodic or sodic-saline.

Sandy soils, although highly suitable for centre-pivot irrigation systems, demand careful management. For example, the Hutton (fine sandy Quartzipsamments; Soil Survey Staff, 1999) form was sampled in Vaalharts and Wildeklawer. The soils were described as deep, fine sandy, dominantly red, freely drained, eutrophic and with parent material that originated from aeolian deposits. Such soils are highly suitable for centre-pivot irrigation (Class I) and to a lesser extent (Class 
II to Class III) for flood irrigation due to the high infiltrability and low water retention. These soils were extensively used under flood irrigation in the Vaalharts Irrigation Scheme, but they soon became waterlogged due to the impermeability of the underlying clay or lime in large areas of the scheme (Gombar and Erasmus, 1976). The other sandy soils, Bloemdal and the Bainsvlei soils sampled at Vaalharts, Wildeklawer and Jackson, offer similar managerial problems as the Hutton soils. Managers were forced to install artificial drainage systems to reclaim these soils in the Vaalharts and also in the Orange-Riet irrigation schemes. Since the occurrence of waterlogging in the late 1970 s, centre-pivot irrigation has progressively replaced flood irrigation (Reinders et al., 2010) because water application can be controlled more accurately (Le Roux et al., 2007).

Swelling clay soils differ in their response to flood irrigation. This is evident when the salt content, $E C_{\mathrm{e}}$ and SAR of the irrigated Valsrivier (Vertic Paleargid) at Vaalharts and the Arcadia (Haplotorrets) of Spitskop are compared with their virgin profiles. The salt content of the irrigated Valsrivier was about $1 \mathrm{t} \cdot \mathrm{ha}^{-1} \cdot \mathrm{m}^{-1}$ lower than the corresponding virgin profile, while that of the Arcadia was about $20 \mathrm{t} \cdot \mathrm{ha}^{-1} \cdot \mathrm{m}^{-1}$ higher than the virgin profile. Le Roux et al. (2007) ascribed this to the morphological features of these soils. The Valsrivier has a fine sandy clay loam texture in the topsoil that gradually changes to fine sandy clay in the subsoil (200 mm - $600 \mathrm{~mm})$ and deep subsoil $(600 \mathrm{~mm}-1600 \mathrm{~mm})$. The colour of the soil also changes from a dark brown in the topsoil to a very dark reddish brown in the subsoil and a dull reddish brown in the deep subsoil. Lime was present in the subsoil and in the deep subsoil, which probably helps to maintain the hydraulic conductivity in the strong, coarse angular blocky structure of the profile. In contrast, the Arcadia has a clayey texture throughout the profile. These clays have extreme swelling properties, which affect the hydraulic conductivity of the soil, depending on the $E C_{\mathrm{e}}$ and the SAR. The SAR increased from 2.3 to 7.3 and with that, fortunately, also the $E C_{\mathrm{e}}$. This probably helped to maintain some hydraulic conductivity in the profile as shown by the long-term salt loss due to leaching as estimated by Van Rensburg et al. (2008). In conclusion, these 2 soil examples confirm the importance of matching soil qualities with irrigation methods. The soil quality of the Valsrivier improved after 5 years of irrigation and is rightfully treated as a Class III soil. The soil quality of the Arcadia deteriorates over time and should not be recommended for irrigation (Class V). The last comment is also applicable to the Sepane (Vertic Haplargids) soil at Jacksons where irrigation induced an SAR of 19 and an $E C_{\mathrm{e}}$ of $1224 \mathrm{mS} \cdot \mathrm{m}^{-1}$, way beyond any acceptable norm.

\section{Soil quality in the Berg River valley}

Another example of how irrigation has improved the soil quality is omnipresent in the Berg River valley. Görgens and De Clercq (2006) reported that irrigation of saline soils with Berg River water $\left(E C_{\mathrm{i}}\right.$ ranging between $25 \mathrm{mS} \cdot \mathrm{m}^{-1}$ and $\left.75 \mathrm{mS} \cdot \mathrm{m}^{-1}\right)$ significantly reduced the $E C_{\mathrm{e}}$ and SAR of soils (Fig. 6). The results demonstrate that after 4 years of irrigation since 1996 (1996 indicates the oldest site with longest irrigation history), the salt in the soil approached equilibrium with the salt in the irrigation water. This was especially true for stony soils. A highly significant correlation was found between the stone content and the SAR of soils. This suggested that patches of high stone content in the soil constitute preferential flow paths resulting in zones with higher leaching and therefore a lower SAR (Moolman et al., 1993). Since the soils of the Berg River
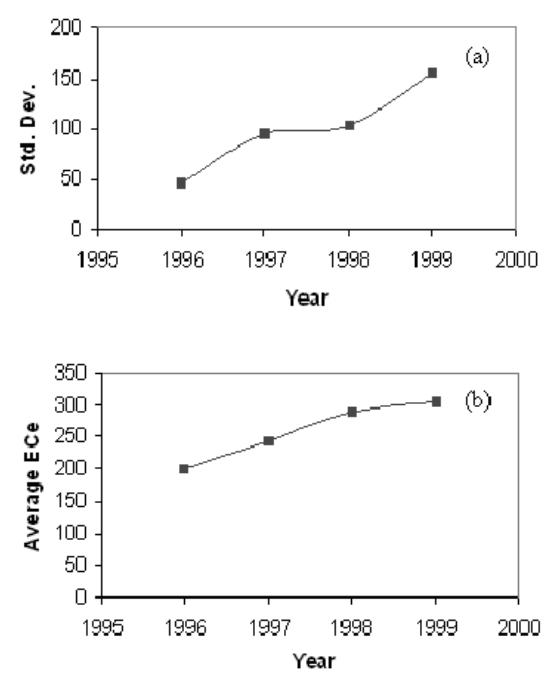

Figure 6

The change in the standard deviation (a) and average (b) soil electrical conductivity (EC) since the inception of irrigation in a block of vineyards. Year refers to the time irrigation commenced in a particular block and sampling was done in all of the blocks during the year 2000 .

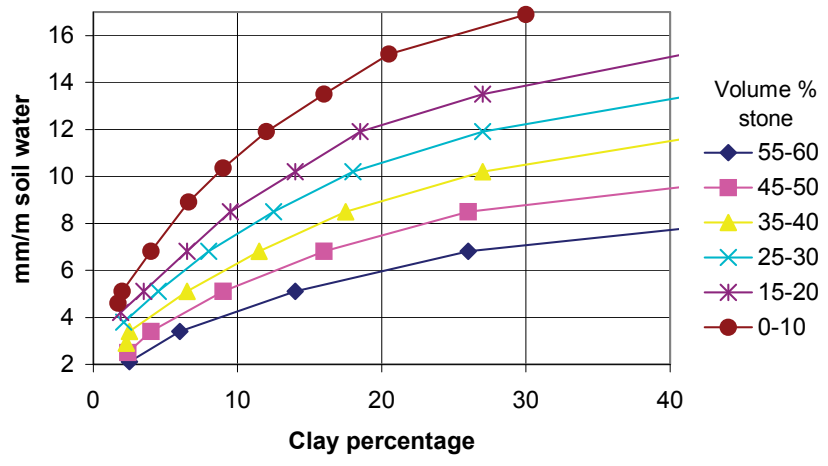

Figure 7

Relationship between clay percentage, soil-water content and volume percentage stone (De Clercq, 2009)

catchment are mostly stony, this phenomenon generally affects irrigation scheduling. Thus, in order to control drainage, relationships were established between clay percentage, soil-water content and percentage of volume the stone would occupy (Fig. 7). The ratios are generally used to determine water storage of especially stony soils, which governs the timing and amount of water application.

The capacity of soils to retain salts was indicated in a saline-water irrigation experiment carried out in the Breede River catchment by Moolman et al. (1999) and De Clercq et al. (2001a). A Trawal soil (varying between a soil family 1100 and 1200, Soil Classification Working Group, 1991) was irrigated with 6 qualities of irrigation water $\left(30 \mathrm{mS} \cdot \mathrm{m}^{-1}, 75 \mathrm{mS} \cdot \mathrm{m}^{-1}, 150\right.$ $\mathrm{mS} \cdot \mathrm{m}^{-1}, 250 \mathrm{mS} \cdot \mathrm{m}^{-1}, 230 \mathrm{mS} \cdot \mathrm{m}^{-1}$ and $500 \mathrm{mS} \cdot \mathrm{m}^{-1}$ ) over a period of 8 years. They found that the soil had a threshold salinity level of about $550 \mathrm{mS} \cdot \mathrm{m}^{-1}$ (the threshold level refers to the maximum amount of salt that the soil could retain under the applied conditions) and that the soil irrigated with water with an EC of $150 \mathrm{mS} \cdot \mathrm{m}^{-1}$ and higher, easily reached the threshold value and stayed there for the duration of the irrigation season. This was done using a $10 \%$ over-irrigation with each irrigation event and 
all extra salt in the system was leached. This response therefore indicated that different soil types had specific salinity threshold values and when irrigated agriculture is planned for a region, the specific salinity threshold values, which can also relate to the cation exchange capacity of the soils, need to be kept in mind.

It was traditionally believed that dryland salinity in the predominantly semi-arid Berg River basin originates from the weathering of sedimentary rocks that had formed under the ocean. However, De Clercq et al. (2010) indicated that the regolith in this semi-arid coastal region contains an abundance of stored salts of marine origin, which accumulated meteorically over a very long period. During this period, either the climate was drier than at present and/or a vegetation cover prevailed. This resulted in less water being discharged from catchments than what presently occurs under the prevailing land use (mainly winter wheat), because of increased water extraction and/or reduced surface runoff. In the present context, it seems increasingly likely that regolith salinity in the Berg River basin is primarily climate-driven and that the role of finer grained Malmesbury shales is not mineralogical, but rather one of hydrological mediation. De Clercq et al. (2010) also indicated therefore that the occurrence of rainfall in the catchment could be correlated with occurrence of salinity and that a negative relationship exists between the 2 parameters (Fig. 8).

It was indicated for the Berg River catchment that the contribution of dryland salts to the water quality of the Berg River was much more significant than that of irrigation return flow. This can also be indicated by the relative percentages of land use in the Berg River catchment (Table 5).

\section{Irrigation and soil water quality, and crop response}

Crops are injured by both the quality of irrigation water and quality of the soil water. The mechanism and type of injury induced by the 2 water sources are different, and the degree of the injury also varies amongst crops. Thus, the effect of the 2 sources on crops will be discussed separately.

- Firstly, the quality of the irrigation water: Irrigation water that contains high concentrations of salt can damage the crop when the foliage is directly wetted with overhead irrigation. The severity of the damage depends on the leaf

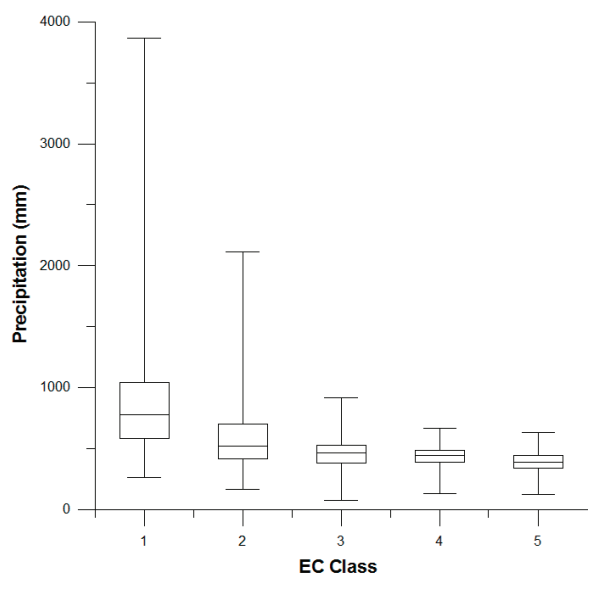

Figure 8

Comparison of precipitation in $\mathrm{mm}$ and electrical conductivity $(E C)$ in groundwater (Class $1=0$ to $70 \mathrm{~ms} \cdot \mathrm{m}^{-1}$; Class $2=70$ to $150 \mathrm{mS} \cdot \mathrm{m}^{-1}$; Class $3=150$ to $300 \mathrm{mS} \cdot \mathrm{m}^{-1}$; Class $4=300$ to 500 $\mathrm{mS} \cdot \mathrm{m}^{-1}$; and Class $5=500$ to $1000 \mathrm{~ms} \cdot \mathrm{m}^{1}$ )

characteristics and rate of salt absorption by the foliage (Maas, 1986). These properties differ widely amongst crops. For example, leaves of deciduous fruit trees (apricots, plums, etc.) absorb $\mathrm{Na}$ and $\mathrm{Cl}$ readily and are severely damaged. Citrus leaves absorb these ions at a slower rate, but still fast enough to cause damage. Avocado and strawberry leaves absorb salt so slowly that foliar injury is negligible. Maas (1986) grouped crops according to their relative sensitivity for salt absorption (Table 6), which is a handy guideline. However, Rhoades and Loveday (1990) stated that the degree of the foliar injury can also be influenced by managerial factors, such as the concentration of the salts in the irrigation water, the frequency of irrigation and the time of irrigation. The higher the concentration of the salt in the irrigation water, the higher the absorption of salt by the leaves. Similarly, a higher irrigation frequency will result in a higher salt concentration in the leaves. The time of irrigation is important because the risk of foliar injury increases as the potential evaporation increases. This is because the rate of absorption increases rapidly as the solution evaporates from the leaf and the salt is concentrated. Once the

\begin{tabular}{|l|c|l|c|l|c|}
\hline \multicolumn{7}{|c|}{ Table 5 } \\
Area of land use for various crops of the Swartland region (De Clercq et al., 2001a) \\
\hline Dryland crops & Area (ha) & Irrigated crops & Area (ha) & Vegetable crops & Area (ha) \\
\hline Wheat & 267600 & Fruit & 4260 & Potatoes & 2234 \\
\hline Oats & 30590 & Vegetables & 7290 & Onions & 240 \\
\hline Legume pastures & 43860 & Grapes & 16600 & Tomatoes & 70 \\
\hline Other pastures & 66100 & Pastures & 3690 & Peas & 900 \\
\hline Other crops & 73920 & Other crops & 460 & Sweet melon & 160 \\
\hline Fallow land & 211330 & & & Other cucurbits & 485 \\
\hline & & & & Brassicas & 720 \\
\hline & & & & Carrots & 220 \\
\hline & & & & Green beans & 140 \\
\hline & & & & Beetroot & 110 \\
\hline & & & & Other & 105 \\
\hline & & & 32300 & & 1900 \\
\hline Total & & & 5 & & 7284 \\
\hline Percentage & 94 & & & & 1 \\
\hline
\end{tabular}




\begin{tabular}{|c|c|c|c|}
\hline \multicolumn{4}{|c|}{$\begin{array}{c}\text { Table } 6 \\
\text { Guidelines to manage the effect of irrigation water quality on crop } \\
\text { (Maas, 1986); relative susceptibility of crops to foliar injury from saline } \\
\text { sprinkling waters }\end{array}$} \\
\hline \multicolumn{4}{|c|}{$\mathrm{Na}$ or $\mathrm{Cl}$ concentrations $\left(\mathrm{mol} \cdot \mathrm{m}^{-3}\right)$ causing foliar injury ${ }^{\mathrm{b}}$} \\
\hline$<5$ & $5-10$ & $10-20$ & $>20$ \\
\hline Almond & Grape & Alfalfa & Cauliflower \\
\hline Apricot & Pepper & Barley & Cotton \\
\hline Citrus & Potato & Corn & Sugar-beet \\
\hline \multirow[t]{4}{*}{ Plum } & Tomato & Cucumber & Sunflower \\
\hline & & Safflower & \\
\hline & & Sesame & \\
\hline & & Sorghum & \\
\hline
\end{tabular}

salts become dry, absorption stops (Maas, 1990). Thus, it is better to irrigate during the night than during the day.

- Secondly, the quality of the soil water: Salt in the irrigation water will eventually be transferred to the soil during irrigation, changing the concentration and composition of salt in the soil water. Since only pure water evaporates at the soil and plant surfaces it implies that the salt will remain in the soil, unless leaching occurs. Thus, irrigation tends to concentrate the salt in soil water, which lowers the osmotic potential and hence the total soil water potential (matric plus osmotic) of the soil (Hillel, 1998). The corresponding decrease in the potential difference between the root xylem and surrounding soil solution results in less water being taken up under conditions of normally adequate water supply. If the transpiration falls below the daily water requirement, water stress and yield losses are inevitable (Moolman et al., 1999; Van Rensburg, 2010).

The degree of water stress and its effect on yields varies amongst crops. Thus, Maas and Hoffman (1977) established a simple equation to manage the effect of soil water quality $\left(E C_{\mathrm{e}}\right)$ on crop yield:

$$
Y_{r}=100-b\left(E C_{\mathrm{e}}-a\right)
$$

where:

$Y_{r}=$ the percentage of the yield of the crop grown under saline conditions relative to that obtained under non-saline conditions

$a=$ the threshold electrical conductivity $\left(\mathrm{mS} \cdot \mathrm{m}^{-1}\right)$ of the saturated soil paste at which yield decreases commence $b=$ the percentage yield loss per unit increase in the electrical conductivity of the soil extract in excess of the threshold value

$E C_{\mathrm{e}}=$ electrical conductivity of the soil extract $\left(\mathrm{mS} \cdot \mathrm{m}^{-1}\right)$

The salt tolerance rating of selected crops based on their threshold value $\left(\mathrm{mS} \cdot \mathrm{m}^{-1}\right)$ and slope of yield reduction $\left(\% \mathrm{mS} \cdot \mathrm{m}^{-1}\right)$ is given in Table 7.

Ehlers et al. (2007) tested the thresholds for South African conditions using wheat, peas, beans and maize. Two experiments were conducted: A pot experiment in the glasshouse facility at the Bloemfontein main campus of the University of the Free State (UFS) and the other at the Field Research Facility of the Department of Soil, Crop and Climate Sciences (UFS). The second experiment used the field lysimeter facility at Kenilworth Experimental Field, about $15 \mathrm{~km}$ north-west of Bloemfontein (29 $01^{\prime} 00^{\prime}$ 'S, $\left.26^{\circ} 08^{\prime} 50^{\prime \prime} \mathrm{E}\right)$. The details on the materials and methods of these experiments are described in Ehlers et al. (2007). The results for one of the crops are presented in Fig. 9, viz. a linear response relationship between relative biomass yield and $\mathrm{EC}$ of the soil water. The results of the intercept (threshold $E C_{\mathrm{sw}}, \mathrm{mS} \cdot \mathrm{m}^{-1}$ ) and slope (relative yield reduction per $\mathrm{mS} \cdot \mathrm{m}^{-1}$ ) represents the threshold which is calculated by means of Eq. (1). The thresholds of peas and 3 other crops are summarised in Table 7. From the results it is clear that the crop-specific thresholds and slope differ between the 2 experiments conducted by Ehlers et al. (2007). These thresholds also differ from those published by Rhoades and Loveday (1990; Table 7).

Salinity thresholds were also determined for grapevines in the Breede River. Details of the experiment were described by De Clercq et al. (2001b). The research was conducted at Robertson ( $\left.33^{\circ} 46^{\prime} \mathrm{S}, 19^{\circ} 46^{\prime} \mathrm{E}\right)$ under conditions of intensive

Table 7

Threshold soil water salinity $\left(E C_{\mathrm{sw}}, \mathrm{mS} \cdot \mathrm{m}^{-1}\right)$ and slope (relative yield reduction per $\left.\mathrm{mS} \cdot \mathrm{m}^{-1}\right)$ according to the regression analysis of the relationship between relative biomass yield and $E C_{\mathrm{sw}}$ of the saline treatments (Ehlers et al., 2007)

\begin{tabular}{|l|c|c|c|c|c|c|}
\hline \multirow{2}{*}{ Crop } & \multicolumn{3}{|c|}{ Threshold $E C_{\text {sw }}\left(\mathbf{m S}^{\cdot} \mathbf{m}^{-1}\right)$} & \multicolumn{3}{c|}{ Slope (relative yield reduction; \% $\mathbf{m S}^{-m^{-1}}$ ) } \\
\cline { 2 - 7 } & Glasshouse & Field & R and L** & Glasshouse & Field & R and $\mathbf{L}^{* *}$ \\
\hline Wheat & 331 & $*$ & 860 & -0.0004 & -0.00011 & -0.0003 \\
\hline Beans & 202 & 82 & 100 & -0.0009 & -0.00086 & -0.0019 \\
\hline Peas & $*$ & 105 & - & -0.0004 & -0.00096 & - \\
\hline Maize & $*$ & 499 & 170 & -0.0008 & -0.00073 & -0.0012 \\
\hline
\end{tabular}

* Negative value

** Rhoades and Loveday (1990) 


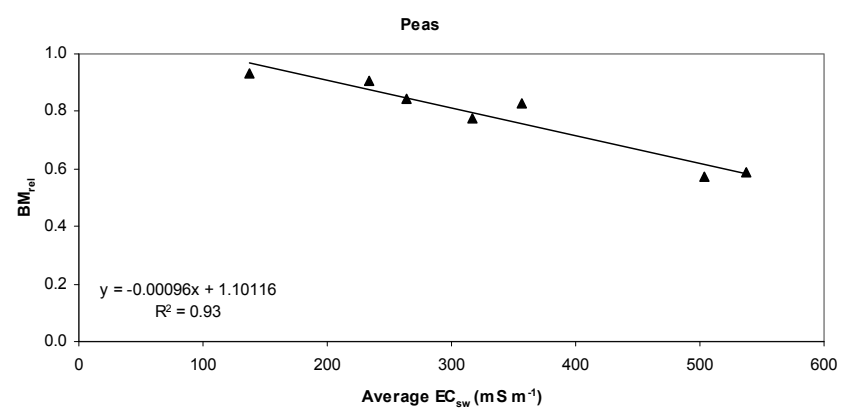

Figure 9

The relationship between the relative biomass yield $\left(B M_{r e}\right)$ and mean seasonal soil-water salinity $\left(E C_{s w}\right)$ for peas (Ehlers et al., 2007)

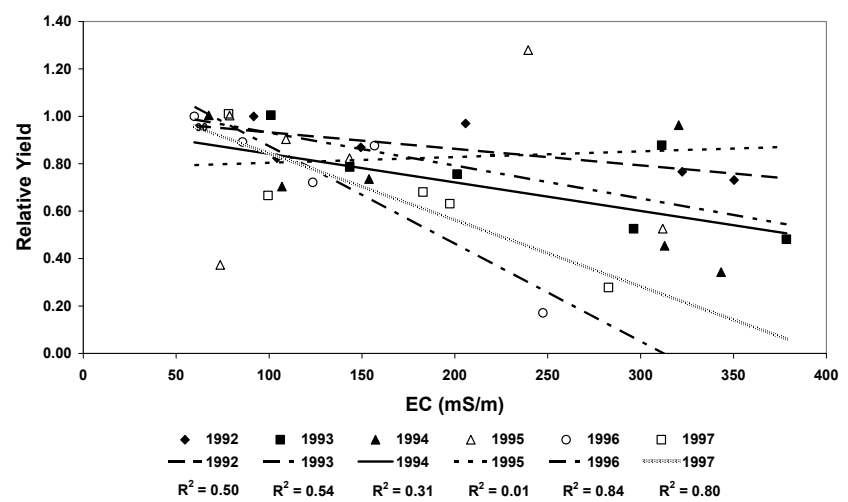

Figure 10

Relationships between relative yield and salinity $\left(E C_{e}\right)$ at Robertson plotted for each year from 1992 to 1997. The data represent seasonal block means (after De Clercq et al., 2001b).

irrigation and at Stellenbosch $\left(33^{\circ} 58^{\prime} \mathrm{S}, 18^{\circ} 50^{\prime} \mathrm{E}\right)$ where supplemental irrigation was applied. In both vineyards the soilwater and soil salinity regimes were measured continuously using a neutron probe and suction cup samplers. Vegetative and reproductive growth was monitored at selected phenological growth stages. The results showed no threshold salinity $E C_{\mathrm{e}}$ value and yield decreased progressively above $E C_{\mathrm{e}}$ of 75


3 times higher than the decreasing rate reported by Maas and Hoffman (1977) as quoted by Ayers and Westcot (1985). A pattern seemed to have emerged, suggesting that, irrespective of whether the inhibitory effect of the saline irrigation treatments on yield is osmotic, toxic ( $\mathrm{Na}$ and/or $\mathrm{Cl})$, or both, the threshold level remains the same over a number of irrigation seasons, but the sensitivity of the crop to levels beyond the threshold increases with the number of seasons of exposure. Irrespective of the specific cultivar response function, the response pattern changed over time and the effect of the treatments was cumulative over time. This result indicated a very important management implication because it suggested that even moderately acceptable water by current standards may, in the longer term, and not necessarily because of soil deterioration, have cumulative debilitating effects leading to premature failure of the vineyard (De Clercq et al., 2001b).

Thus, the results confirmed the view of Maas (1986) that the salt-tolerance guidelines cannot provide a fully accurate, quantitative measure of crop yield losses to be expected from salinity for every situation. The actual response to salinity varies with growth conditions such as climate, irrigation management, agronomic management and crop response to saline conditions.

Based on the above results, Ehlers et al. (2007) determined the effect of water quality on the water production function of crops. The hypothesis was that the reduction in water uptake induced by osmotic potential of the soil water should correlate with the reduction in yield. The relationship as proposed by Stewart et al. (1977) was used to determine reduction of crop yields:

$$
1-\frac{Y_{\mathrm{a}}}{Y_{\mathrm{m}}}=b\left[1-\left(\frac{E T_{\mathrm{a}}}{E T_{\mathrm{m}}}\right)\right]
$$

where:

$Y=$ actual crop biomass yield $\left(\mathrm{t} \cdot \mathrm{ha}^{-1}\right)$ of a treatment

$Y_{\mathrm{m}}^{\mathrm{a}}=$ biomass yield $\left(\mathrm{t} \cdot \mathrm{ha}^{-1}\right)$ of the control treatment with no water stress

$E T_{\mathrm{a}}=$ actual crop evapotranspiration $(\mathrm{mm})$ of a saline treatment

$E T_{\mathrm{m}}=$ potential crop evapotranspiration $(\mathrm{mm})$ of the control treatment

$b=$ slope of the relationship between relative yield and relative evapotranspiration

Taking $Y_{\mathrm{m}}$ and $E T_{\mathrm{m}}$ as the biomass yield and evapotranspiration (ET) of the control treatments, the analysis of the results gives a linear relationship between relative evapotranspiration and relative yield as illustrated by Fig. 11 for the combined data of all of the crops. This is a clear indication that the relative decrease in growth of all the crops was directly proportional to the relative decrease in $E T$ caused by the decreasing osmotic potential with increased salinity. Hence, this proves that, irrespective of the differences in salt tolerance of the different crops, in all cases the reduction in growth was proportionally related to the increase in plant-water stress induced by lower water uptake. From the results it is clear that the guidelines provided in the literature are rather static, while a more dynamic approach is required. This can only be achieved through models such as SWB and SWAMP (Singels et al., 2010).

\section{Conclusion and recommendations}

This review shows that remarkable progress has been made on salinity research over the past 40 years since the establishment of the WRC. The diversity and range of the WRC projects makes it virtually impossible to cover all aspects thoroughly in a paper of limited length. Thus, it was decided to narrow the focus down to salinity guidelines associated with the management of rivers, soils and crops. From the research examples used in the Lower Vaal, Riet, Berg and Breede Rivers it has been shown that the quality of the river water depends heavily on the management of the irrigated soils and crops. Fortunately, very effective soil-suitability guidelines for the selection of irrigation soils were developed and enforced by the government during the development of major irrigation schemes. However, management plays a pivotal role in sustaining the quality of the soils. Long-term irrigation case studies along the Lower Vaal River and Breede River showed that the quality of soils can be improved with irrigation. The opposite is also true where mismanagement has occurred. Research on the salinity threshold values of the major crops (grapevines, wheat, maize, groundnuts, etc.) confirmed the empiric nature of the guidelines. It was suggested that a more dynamic approach be used for managing salinity under irrigation at farm level, i.e. the use of models. 




Figure 11

Relationship between the relative biomass yield $\left(B M_{\text {rel }}\right)$ and the relative cumulative evapotranspiration (Cum $E T_{\text {ree }}$ ) for all the crops (Ehlers et al., 2007)

The following are considered to be important research and development needs:

- The effect of irrigation on the quality of soils needs to be determined for the major irrigation schemes. The last survey was done in the late $1980 \mathrm{~s}$.

- Survey methods for determining the spatial and temporal distribution of salt in soils should be developed and tested.

- Survey methods for determining the spatial and temporal distribution of waterlogging in irrigated fields.

- The combined effect of salinity and waterlogging on crops.

- Formulation of best salinity management practices and the application thereof on field, farm and scheme level.

\section{References}

AYERS RS and WESTCOT DW (1985) Water Quality for Agriculture. FAO Irrigation and Drainage Paper No. 29 REV 1. FAO, Rome. $174 \mathrm{pp}$.

BACKEBERG GR (2003) Water usage and irrigation policy. In: Nieuwoudt L and Groenewald J (eds.) The Challenge of Change: Agriculture, Land and the South African Economy. University of Natal Press, Pietermaritzburg, South Africa.

BACKEBERG GR, BEMBRIDGE TJ, BENNIE ATP, GROENEWALD JA, HAMMES PS, PULLEN RA and THOMSON H (1996) Policy Proposal for Irrigated Agriculture in South Africa. WRC Report No. KV96/96. Water Research Commission, Pretoria, South Africa. $119 \mathrm{pp}$.

BESTER HC and LIENGME DP (1989) The Evaluation of Land for Irrigation: A Literature Review. SIRI Report no GB/A/90/3. Soil and Irrigation Research Institute, Pretoria, South Africa. 22 pp.

CASS A (1986) Irrigation Return Flow Water Quantity and Quality Modelling in South Africa. Dept. of Soil Science, University of Natal, Pietermaritzburg, South Africa. 110 pp.

CULLIS J, GÖRGENS A and ROSSOUW N (2005) First Order Estimate of the Contribution of Agriculture to Non-Point Source Pollution in Three South African Catchments: Salinity, Nitrogen and Phosphorus. WRC Report No. 1467/2/05. Water Research Commission, Pretoria, South Africa. $73 \mathrm{pp}$.

DE CLERCQ WP, FEY MV, MOOLMAN JH, WESSELS WPJ, EIGENHUIS B and HOFFMAN E (2001a) Establishing the Effects of Saline Irrigation Water and Managerial Options on Soil Properties and Plant Performance. WRC Report No. 695/1/01. Water Research Commission, Pretoria, South Africa. 220 pp.

DE CLERCQ WP, FEY MV, MOOLMAN JH, WESSELS WPJ, EIGENHUIS B and HOFFMAN E (2001b) Experimental Irrigation of Vineyards with Saline Water. WRC Report No. 522/1/01. Water Research Commission, Pretoria, South Africa. 220 pp.

DE CLERCQ WP, JOVANOVIC N, FEY M (2010) Land Use Impacts on Salinity in Berg River Water: Research on Berg River Water Management. WRC Report No. 1503/1/10. Water Research Commission, Pretoria, South Africa. 126 pp.
DE VILLIERS S (2007) The deteriorating nutrient status of the Berg River, South Africa. Water SA 33 659-664.

DU PLESSIS HM (1995) Researching and applying measures to conserve natural irrigation resources. Proc. South African Irrigation Symposium. 4-6 June 1991, Durban. WRC Report No. TT 71/95. Water Research Commission, Pretoria, South Africa. 61-69.

DU PREEZ CC, STRYDOM MG, LE ROUX PAL, PRETORIUS JP, VAN RENSBURG LD and BENNIE ATP (2000) Effect of Water Quality on Irrigation Farming along the Lower Vaal River: The Influences on Soils and Crops. WRC Report No. 740/1/100. Water Research Commission, Pretoria, South Africa. 157 pp.

DWAF (DEPARTMENT OF WATER AFFAIRS AND FORESTRY, SOUTH AFRICA) (1986) Management of the water resources of the Republic of South Africa. Department of Water Affairs, Pretoria, South Africa. 419 pp.

EHLERS L, BARNARD JH, DIKGWATLHE SB, VAN RENSBURG LD, CERONIO GM, DU PREEZ CC and BENNIE ATP (2007) Effect of Irrigation and Water Table Salinity on the Growth and Water Use of Selected Crops. WRC Report No. 1359/1/06. Water Research Commission, Pretoria, South Africa. $150 \mathrm{pp}$.

EHLERS L, BENNIE ATP and DU PREEZ CC (2003) The Contribution of Root Accessible Water Tables Towards the Irrigation Requirements of Crops. WRC Report No. 1089/1/03. Water Research Commission, Pretoria, South Africa. 148 pp.

ELLINGTON RG, USHER BH and VAN TONDER GJ (2004) Quantification of the Impact of Irrigation on the Aquifer Underlying the Vaalharts Irrigation Scheme. WRC Report No. 1322/1/04. Water Research Commission, Pretoria, South Africa. 163 pp.

FEY MV and DE CLERCQ WP (2004) A Pilot Study Investigating the Role of Dryland Salinity in the Quality of the Water of the Berg River. WRC Report No. 1342/1/04. Water Research Commission, Pretoria, South Africa. 83 pp.

FOURIE JM (1976) Mineralization of Western Cape Rivers: An Investigation into the Deteriorating Water Quality Related to Drainage from Cultivated Lands along Selected Catchments, with Special Reference to the Great Berg River. Ph.D. Thesis, University of Stellenbosch, Stellenbosch, South Africa. 146 pp.

GOMBAR O and ERASMUS CJH (1976) Vaalharts Ontwateringsprojek. Technical Report No. GH2897. Department of Water Affairs, Pretoria, South Africa. 60 pp.

GÖRGENS A and DE CLERCQ WP (2006) Water Quality Information Systems for Integrated Water Resource Management: The Riviersonderend-Berg River System. WRC Report No. TT 262/06. Water Research Commission, Pretoria, South Africa. 34 pp.

GREEF GJ (1990) Detailed Geohydrological Investigations in the Poesjesnel River Catchment in the Breede River Valley with Special Reference to Mineralization. WRC Report No. 120/1/90. Water Research Commission, Pretoria, South Africa. 238 pp.

HALL GC and DU PLESSIS HM (1979) The Effects of Irrigation in the Upper Reaches of the Sundays River on Chloride Concentration in Lake Mentz - A Rough Estimate. WRC Co-ordinating Research and Development Committee for Water Quality report. Water Research Commission, Pretoria, South Africa. 120 pp.

HENSLEY M and LAKER MC (1980) A proposed integrated procedure for the identification, delineation, evaluation and planning of irrigable land. Proc. $9^{\text {th }}$ National Congress of Soil Sci. Soc. of S.A. Tech. Comm. No.174. Department of Agriculture, Forestry and Fisheries, Pretoria, South Africa. 15-22.

HERALD J (1999) Hydrosalinity Studies in the Coerney Valley. Volume 1: Final Report. WRC Report No. 195/1/99. Water Research Commission, Pretoria, South Africa. 133 pp.

HEROLD CE and BAILEY AK (1996) Long Term Salt Balance of the Vaalharts Irrigation Scheme. WRC Report No. 420/1/96. Water Research Commission, Pretoria, South Africa. 120 pp.

HILLEL D (1998) Environmental Soil Physics. Academic Press, London. 757 pp.

IRRIGATION PLANNING STAFF (1980) A method of evaluating land for irrigation development. Proc. $9^{\text {th }}$ National Congress of Soil Sci. Soc. of S.A. Tech. Comm. No. 174. Department of Agriculture, Forestry and Fisheries, Pretoria, South Africa. 10-14.

KIENZLE SW (1990) The Salinity of the Breede River and Its Tributaries Between Brandvlei Dam and HMO4: Summary of 
Daily Data for the Hydrological Year 1989/90. $8^{\text {th }}$ Internal Report on Breede River Salination Programme. Hydrological Research Institute, Department of Water Affairs and Forestry, Pretoria. 35 pp.

LE ROUX PAL, DU PREEZ CC, STRYDOM MG, VAN RENSBURG LD and BENNIE ATP (2007) Effect of irrigation on soil salinity profiles along the Lower Vaal River, South Africa. Water SA 33 473-478.

MAAS EV and HOFFMAN GJ (1977) Crop salt tolerance - current assessment. J. Irrig. Drain. Div. 103 115-134.

MAAS EV (1986) Salt tolerance of plants. Appl. Agric. Res. 1 12-26.

MAAS EV (1990) Crop salt tolerance. In: Tanji KK (ed.) Agricultural Salinity Assessment and Management. Am. Soc. Civ. Eng., New York.

MACVICAR CN (1976) Classifying and Mapping Soils in the Field for Detailed Surface Irrigation Planning. SIRI Report No. 848/91/76. Soil and Irrigation Research Institute, Pretoria, South Africa. $11 \mathrm{pp}$.

MOOLMAN JH, VAN ROOYEN PC and WEBER HW (1993) The effect of irrigation practices in the Breë River Valley on the salt content of a small river. Irrig. Sci. 4 103-116.

MOOLMAN JH (1993) An Evaluation of a Range of Computer Models Simulating the Transport of Solutes and Water in the Root Zone of Irrigated Soils. WRC Report No. 196/1/93. Water Research Commission, Pretoria, South Africa. 196 pp.

MOOLMAN JH, DE CLERCQ WP, WESSELS WPJ, MEIRI A and MOOLMAN CG (1999) The Use of Saline Water for Irrigation of Grapevines and The Development of Crop Salt Tolerance Indices. WRC Report No. 303/1/1999. Water Research Commission, Pretoria, South Africa. 26 pp.

NEL DJ (1988) Fisies-Chemiese Eienskappe van Gronde Langs die Mooirivier wat oor ' $n$ Lang Termyn Besproei is. WRC Report No. 135/1/88. Water Research Commission, Pretoria, South Africa. 310 pp.

NIEUWOUDT WL, DOCKEL JA and MOSAKA DD (2008) Towards the Establishment of Water Market Institutions for Effective and Efficient Water Allocation in South Africa. WRC Report No. 1569/1/08. Water Research Commission, Pretoria, South Africa. 140 pp.

NINHAM SHAND (2004) Water Management Plan for the OrangeRiet Water Users Association. Department of Water Affairs and Forestry. Pretoria, South Africa. $12 \mathrm{pp}$.

REINDERS FB, VAN DER STOEP I, LECLER NL, GREAVES KR, VAHRMEIJER JT, BENADÉ N, DU PLESSIS FJ, VAN HEERDEN PS, STEYN JM, GROVÉ B, JUMMAN A and ASCOUGH G (2010) Standards and Guidelines for Improved Efficiency of Irrigation Water Use from Dam Wall Release to Root Zone Application: Supplementary Information. WRC Report No. TT 467/10. Water Research Commission, Pretoria, South Africa. $26 \mathrm{pp}$.

RHOADES JD and LOVEDAY J (1990) Salinity in irrigated agriculture. In: Steward AB and Nielsen DR (eds.) Irrigation of Agricultural Crops. Agron. Soc. Am., Madison, Wisconsin.

SCHOEMAN JL (1987) Die Besproeibaarheid van Grondvorms en -Series in die Vrystaatstreek. SIRI Report No. GB/A/89/24. Soil and Irrigation Research Institute, Pretoria, South Africa. 10 pp.
SCOTNEY DM and VAN DER MERWE AJ (1995) Irrigation: Longterm viability of soil and water resources in South Africa. Proc. South African Irrigation Symposium. 4-6 June 1991, Durban. WRC Report No. TT 71/95. Water Research Commission, Pretoria, South Africa. 50-60.

SINGELS A, ANNANDALE JG, DE JAGER JM, SCHULZE RE, INMAN-BAMBER NG, DURAND W, VAN RENSBURG LD, VAN HEERDEN PS, CROSBY CT, GREEN GC and STEYN JM (2010) Modelling crop growth and crop water relations in South Africa: Past achievements and lessons for the future. S. Afr. J. Plant Soil 27 49-65.

SOIL CLASSIFICATION WORKING GROUP (1991) Soil Classification: A Taxonomic System for South Africa. Department of Agricultural Development, Pretoria, South Africa. 257 pp.

SOIL SURVEY STAFF (1999) Keys to Soil Taxonomy ( $8^{\text {th }}$ edn.). Pocahontas Press Inc., Blacksburg, Virginia.

STANDER JVR (1987) Fighting SA's salinity problem. SA Water Bull. 13 10-13.

STEWART JL, DANIELSON RE, HANKS RJ, JACKSON EB, HAGON RM, PRUIT WO, FRANKLIN WT and RILEY JP (1977) Optimizing Crop Production through Control of Water and Salinity Levels in the Soil. Utah Water Research Laboratory Progress Report No. 151, Logan, Utah.

STREUTKER A, VAN VLIET N and MOLENAAR HW (1981) Besproeiing, gewasopbrengs en dreinering op die Vaalhartsbesproeiingskema: 2 . Die voorkoms van verbrakte grond en die invloed van dreinering daarop. Water SA 7 175-184.

THE NON-AFFILIATED SOIL ANALYSIS WORK COMMITTEE (1990) Handbook of Standard Soil Testing Methods for Advisory Purposes. Soil Science Society of South Africa, Pretoria, South Africa. $138 \mathrm{pp}$.

TURNER D (1991) Minimum Data Set for Describing Soil Profiles. Institute for Soil, Climate and Water, Pretoria, South Africa. 11 pp.

UNITED STATES SALINITY LABORATORY STAFF (1969) Diagnosis and Improvement of Saline and Alkaline Soils. U.S. Laboratory Handbook 60, USDA, Washington. 160 pp.

VAN DER MERWE AJ (1965) Certain Fundamental Characteristics of Selected Alkali Soils. M.Sc. Agric. thesis. University of the Free State, Bloemfontein, South Africa. 109 pp.

VAN RENSBURG LD, STRYDOM MG, DU PREEZ CC, BENNIE ATP, LE ROUX PAL and PRETORIUS JP (2008) Prediction of salt balances in irrigated soils along the lower Vaal River, South Africa. Water SA 34 11-17.

VAN RENSBURG LD (2010) Advances in soil physics: Application in irrigation and dryland crop production. S. Afr. J. Plant Soil 27 9-18.

VERSTER E and STOFBERG JA (1974) Besproeiingsmoontlikhede van Dertien Plase Langs die Blyde- en Olifantsrivier. SIRI Report No. 786/7/74. Soil and Irrigation Research Institute, Pretoria, South Africa. 12 pp.

VILJOEN MF, ARMOUR RJ, OBERHOLZER JL, GROSSKOPF M, VAN DER MERWE B and PIENAAR G (2006) Multi-Dimensional Models for the Sustainable Management of Water Quantity and Quality in the Orange-Vaal-Riet Convergence System. WRC Report No. 1352/1/06. Water Research Commission, Pretoria, South Africa. $281 \mathrm{pp}$. 
http://dx.doi.org/10.4314/wsa.v37i5.11 Available on website http://www.wrc.org.za

ISSN 0378-4738 (Print) $=$ Water SA Vol. 37 No. 5 WRC 40-Year Celebration Special Edition 2011 ISSN 1816-7950 (On-line) = Water SA Vol. 37 No. 5 WRC 40-Year Celebration Special Edition 2011 